Acta vet. scand. 1961, 2, $22-31$.

From the Department of Obstetrics \& Gynaecology, Royal Veterinary College, Stockholm, Sweden.

\title{
THE PROLIFERATION OF GERM CELLS IN THE TESTES OF BULL CALVES AND YOUNG BULLS
}

\author{
By \\ M. Abdel-Raouf ${ }^{1}$ )
}

In the sex cords of newborn animals two types of cells are present. These types have been described in cattle foetuses by Hashimoto \& Eguchi (1955) and Santamarina \& Reece (1957), and in newborn calves by Masui (1919), Lagerlöf (1934, 1939), Hooker (1944), Santamarina \& Reece (1957) and Courot (1958). One type of cells consists of the gonocytes (also called primordial germ cells or differentiated germ cells) and the other one presents supporting cells (also called indifferent cells).

Two different theories exist about the fate of these cells. According to Regaud (1900), Stieve (1930), Masui (1919), Schinz \& Slotopolsky (1924), Hargit (1926), Romeis (1926), and Santamarina \& Reece (1957), the gonocytes degenerate after birth while the supporting cells proliferate and give rise to spermatogonia and at a later stage of development to Sertoli cells. On the other hand, according to Bouin (1924), Sand (1933), Clermont \& Perey (1957), Courot (1958), and others, the gonocytes are the mother cells of spermatogonia and the indifferent cells develop into Sertoli cells.

According to Lagerlöf (1939), the primordial germ cells are absent in hypoplastic testes of young calves and because of this, a diagnosis of hypoplasia may be made with fairly great certainty before the difference in size between the two testes is clearly marked.

1) Present address : Faculty of Veterinary Medicine, Giza, Egypt, U.A.R. 
It is the aim of this work to study the proliferation of embryonic germ cells in the testes and trace them until the adult types are attained.

\section{MATERIAL AND METHODS}

Observations described here were made on the testes of 50 bulls of the Swedish Red-and-white Breed, varying in age from 2 days to 44 weeks. The testes from one foetus of the same breed are also included. Small blocks of the testes were fixed in Bouin's fluid within one hour after slaughter or castration. For control small fragments were also fixed immediately after slaughter or castration in Bouin's fluid as well as in acetic-alcohol fixative $(1: 3)$. The slices were dehydrated and embedded in paraffin. Sections were cut at $5 \mu$ and stained with Feulgen's nuclear stain, Mayer's haemalum as well as with Heidenhain's iron haematoxylin.

\section{OBSERVATIONS}

\section{The foetus}

The foetus was about seven months old. Two types of cells can be distinguished in the solid sex cords (Fig. 1). One of these consists of small indifferent cells. These possess round nuclei that lie close to the basement membrane, to make a complete layer. In some cords this layer is interrupted by the presence of one or more gonocytes. The small cells are interpreted as the indifferent supporting cells and from their position the name bis-cells (basal indifferent supporting cells) has been adopted throughout this work. No cell borders could be observed by the technique applied, only small nuclei, 5-7 $\mu$ in diameter, containing coarse chromatin granules. Some of these cells exhibited different stages of mitosis.

The other type of cells consists of large cells to which the name gonocyte is given in current literature. These are large cells, basally located between the bis-cells as well as centrally in the sex cords. The nucleus is large, light-stained, spherical and contains fine chromatin granules and one or two globular nucleoli which are strongly stained in comparison with the chromatin granules. A distinct cell membrane is observed and in some instances the cells were observed in mitosis. The chromosomes in this case are clearly defined and the chromosomal plate in the 


\section{PHOTOMICROGRAPHS OF TESTES}

Acetic-Alcohol Fixative, H \& E
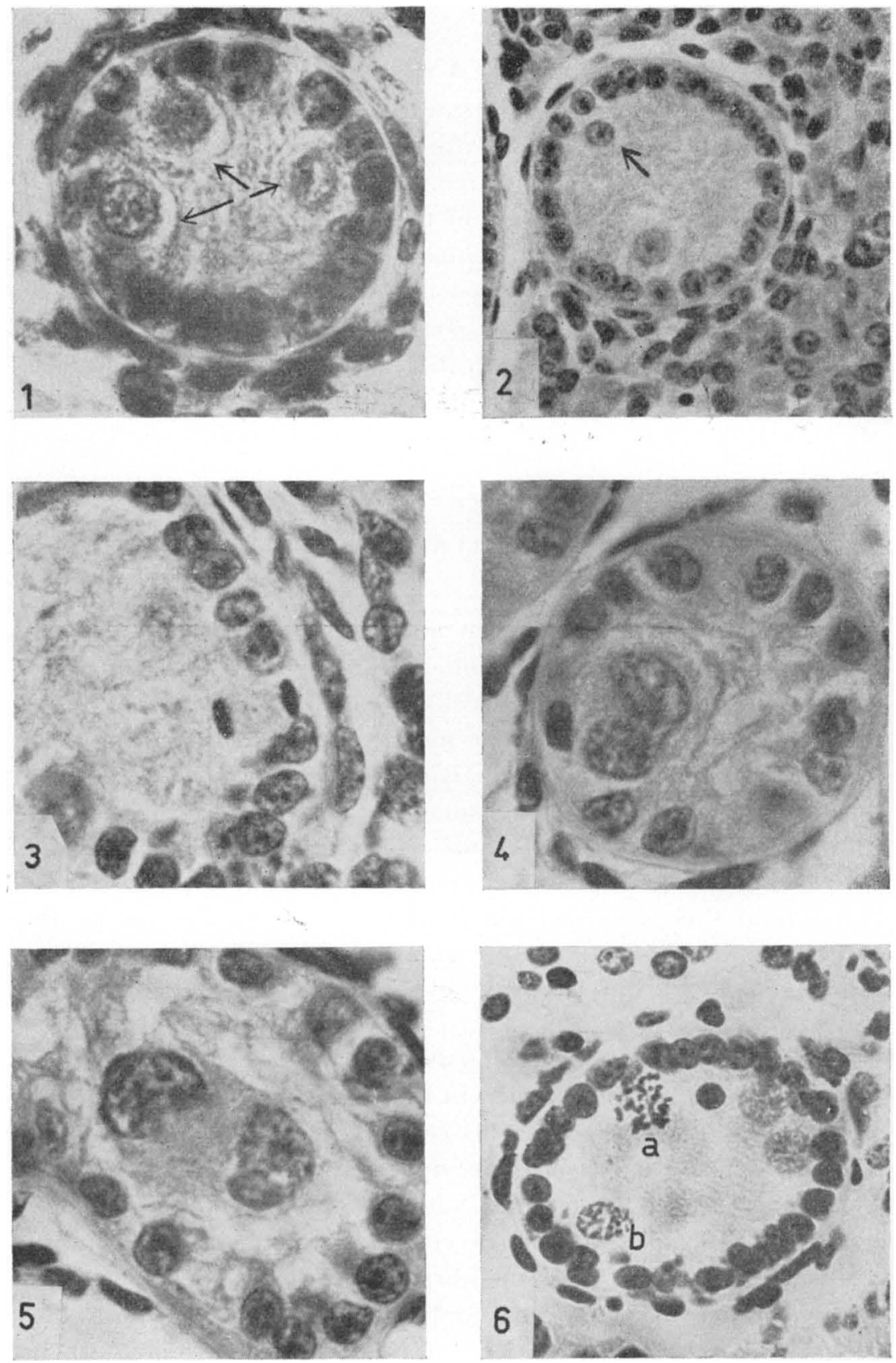
corresponding stages of division is large in comparison with that of the bis-cells.

\section{1-week-old calves}

The bis-cells ranged between 13 and 15 cells per cross-sectioned sex cord. No change in their morphological structure is observed with the exception of increased frequency of dividing cells. The gonocytes are in most cords located in the centre and their number varied between one and four cells per cross-sectioned sex cord. They were observed in 75 per cent of the examined sex cords.

\section{4-week-old calves}

At this age cells resembling the bis-cells in appearance were observed to be located towards the centre of the sex cords (Fig. 2). These cells are given the name cis-cells (central indifferent supporting cells) throughout this work. The cis-cells are apparently the product of the bis-cells. The latter divide mitotically, each giving rise to two new cells of the same structure. The new cells are either located at the basement membrane or at the centre of the sex cord. In the prophase stage of the bis-cells, the chromosomes are thick and short and lie in a compact bunch. Individual chromosomes are not clearly seen. In the metaphase stage the mitotic spindle exhibits two different positions. Some spindles lie perpendicular to the basement membrane and others parallel to the membrane. From the first position one of the daughter cells will lie next to the basement membrane and the other one towards the centre of the sex cord. From the second position

Fi g. 1. Testis from a 7-month-old foetus showing a solid sex cord with bis-cells and three gonocytes (arrows). $-\times 1500$.

Fi g. 2. Testis from a 4-week-old calf showing a cis-cell (arrow). $-\times 750$.

Fig. 3. Testis from a 4-week-old calf showing a bis-cell in a late anaphase stage. $-\times 1500$.

F i g. 4. Testis from a 4-week-old calf showing an early degenerative stage of a gonocyte (compare with the gonocyte in Fig. 1). $-\times 1500$.

Fig. 5. Testis from a 4-week-old calf showing a gonocyte in an advanced stage of degeneration. $-\times 1500$.

Fig. 6. Testis from a 4-week-old calf showing two gonocytes in mitotic division, (a) metaphase, (b) prophase. $-\times 750$. 
both the daughter cells lie adjacent to the basement membrane. Cell division has been followed through to the anaphase (Fig. 3), and later to the telophase after which both cells go back to the resting stage and the chromosomes are no longer visible.

Many gonocytes have lost their regularity in form and size and have nearly doubled in size. The nuclear wall is no longer spherical but is depressed from one side, so that the nucleus appears somewhat kidney shaped (Fig. 4). In the concavity formed in the nuclear membrane is situated a granular mass. This mass stains brightly with eosin. In more advanced stages of degeneration, the nuclear distortion or constriction increases in depth so that the nucleus becomes more or less horse-shoe shaped. The constriction continues further until a complete division of the nucleus is attained. Now both halves of the nucleus, which are rather pyramidal in shape, are widely separated from each other with the cytoplasmic mass filling the space in between (Fig. 5). These nuclear changes are interpreted as a degenerative process in the gonocytes. Some other gonocytes are seen in proper mitotic division with clearly defined and long chromosomes (Fig. 6).

\section{8-week-old calves}

Both bis- and cis-cells have increased in number. The average number of the bis-cells is 25 and that of the cis-cells is 1.6 cells per cross-sectioned sex cord. Many of the gonocytes observed are degenerating. Spermatogonia were observed to be formed at this age. These possess a large nucleus in comparison with that of the mother gonocyte, with crustlike chromatin and one or two nucleoli.

\section{2-week-old calves}

The histological picture is nearly the same as in the previous age group. The number of bis-cells is about the same, while the cis-cells had increased to some two cells per cross-sectioned sex cord. The large degenerating gonocytes are rarely seen. Only 26 per cent of the examined cords exhibited these cells. The average number of spermatogonia per cross sectioned cord amounts to 0.9 cells and about 53 per cent of the examined tubules presented these cells. 


\section{6-week-old calves}

The process of lumen formation has just begun in the solid cords. The cords present only three types of cells. These are the bis-cells (mean 26 cells per cross-sectioned cord), the cis-cells (mean 2.5 cells), and the spermatogonia (mean 2.2 cells). The previously described gonocytes are no longer seen.

\section{0- and 24-week-old calves}

A new type of cell appears in the newly canalised cords - the primary spermatocyte. The spermatocytes are found only in few tubules and in a varying number. The cells are large and spherical with a large nucleus exhibiting distinct chromosomes in different form according to the stage of division. The three types of cells previously described in the 16-week-old calves are still present. The bis-cells have begun to decrease in number and amount only to 22 and 21 cells per cross-sectioned tubule in the 20- and 24week-old animals respectively. The cis-cells averaged 5.3 cells in the 20-week-old animals and 3.9 in the 24 -week-old animals. In contrast to the decrease in the number of the bis-cells and the cis-cells, the spermatogonia increase in number and reach an average of 3.4 and 7.7 cells in the 20- and 24-week-old animals respectively.

\section{8-week-old calves}

The primary spermatocytes are now observed in 55 per cent of the examined tubules (mean 5.2 cells per cross-sectioned tubule). Spermatids, which make their appearance in this age, are small, spherical cells, each containing a spherical nucleus with several darkly stained chromatin granules. The average number of spermatids reaches 0.3 cells per cross-sectioned tubule and they are present in 4 per cent of the examined tubules. In some of the longitudinally sectioned tubules, isolated sperm were observed. Sertoli cells were also clearly seen at this age. They are identified by their characteristic nuclei, triangular or oval in shape, with a wrinkled and folded nuclear membrane giving the impression of darkely pigmented filaments running along the longitudinal axis of the nucleus.

\section{2- to 44-week-old calves}

The tubules present eight types of cells. These are the bisand cis-cells, Sertoli cells, spermatogonia, primary spermatocytes, 
secondary spermatocytes, spermatids and sperm. From 32 weeks until the 40th week the adult cells increase in number and the bis-cells as well as the cis-cells decrease in number due to their transformation to Sertoli cells. The cis-cells are no longer seen by the age of 36 weeks and all the bis-cells are transformed to Sertoli cells by the age of 40 weeks. From the age of 44 weeks onwards the changes met with in the seminiferous tubules are of a quantitative nature. The different cell types increase in number with the exception of spermatogonia and Sertoli cells. The average number of the former type is stabilised at about 25 cells and of the latter one about 15 cells per cross sectioned tubule by the age of 44 weeks.

\section{DISCUSSION}

The presence of two types of cells in the testis of the newborn has been shown by many investigators for mammalian and avian testes. In foetal and newborn bovine males these cells have been described by Masui (1919), Lagerlöf (1934, 1939), Hooker (1944), Hashimoto \& Eguchi (1955), Santamarina \& Reece (1957), and Courot (1958) inter alia. In some species both types of cells were described to be present during the prenatal life but the gonocytes were stated not to be present by the time of birth. In the guinea pigs, Bookhout $(1937 \mathrm{a}, \mathrm{b}$,$) described in detail the postnatal$ development of the gonocytes and the supporting cells. He concluded that the gonocytes play no part in the production of the functional germ cells and that at birth none of these cells are present in the sex cord. Recently Santamarina \& Reece (1957) concluded that the so-called primordial germ cells in the bovine testis had nothing to do with the definitive germ cells.

Throughout the present work it was quite clear that the gonocytes and the supporting cells are different kinds of cells, each behaving in a particular manner, quite different from that of the other kind. The gonocytes divide and give rise to spermatogonia and the supporting cells transform into adult Sertoli cells. The failure of penetration of the gonocytes to the embryonic testis causes complete lack of germinal epithelium in the adult. Examples have been described in cattle by Lagerlöf (1939) and it has been postulated by Del Castelo, Trabuco \& De La Plaza (1947) that a similar condition can exist in human beings. With the aid of electron microscopy it has been observed that both types of cells exhibit different ultrastructure. The indifferent 
supporting cells were observed to possess an apparent cell membrane and the nucleus to exhibit an ultrastructure similar to that of the Sertoli cells. The ultrastructure of the gonocyte resembles that of the spermatogonia (Nicander, Abdel-Rauof \& Crabo - in press). The statement of Santamarina \& Reece (1957) that the supporting cells give rise to both spermatogonia and Sertoli cells and that the gonocytes have nothing to do with the definitive germ cells does not receive any support from the present study.

It can be asked, then, why some of the gonocytes degenerate after birth. Von Roth (1891) asserted that the generating cells are used as a nutritive material in the process of development of the sex cords. Patterson (1908) believed that this "amitotic division" is the result of special physiological conditions which create a stimulus to cell division. It appears that the reason for the degeneration is the lack of sufficient stimulus in the form of hormones. Nutritions are supposed to reach the germ cells via Sertoli cells. The bis-cells are evidently immature Sertoli cells (as revealed by electron microscopy). One may suppose that the nutritive substances are to a great extent exhausted by the biscells which showed greater activity both prenatally and postnatally than the gonocytes. Or that the bis-cells had not attained the ability to transfer the nutritive substances to the gonocytes at such early stages of development. In this connection, it appears that the indifferent supporting cells are not as sensitive as the gonocytes. Lagerlöf (1934) has shown that Sertoli cells resist high temperature produced by scrotal insulation, while the germ cells undergo degeneration.

Hooker (1944) described some indifferent cells lying towards the centre of the solid sex cords at the age of $1 \frac{1 / 2}{2}$ months, but he did not state their origin. It is evident from the present observations that these cells are the product of the bis-cells. The reason for their central positions could be the lack of space at the basement membrane resulting from the rapid increase in the number of bis-cells in comparison with the more sedate increase in the diameter of the sex cords as shown by Abdel-Raouf (1960).

The maximal number of bis-cells was recorded between the ages of 12 and 16 weeks. From this age onwards the cells did not show any mitotic activity but were transformed to Sertoli cells. The number of Sertoli cells per cross-sectioned tubule is about 15 cells in the adult animal. The decrease in number from 
26 to 15 is mainly due to the increase in size of the seminiferous tubules and the increase in number of germ cells as well as the increase in length of the tubules. Thus the fixed number of Sertoli cells is thinned out along a longer tubules perimeter.

\section{REFERENCES}

Abdel-Raouf, M.: Acta Endocrinol., 1960, Suppl. 49.

Bookhout, C. G.: Z. Zellforsch., 1937 a, 25, 728./1937 b, 25, 749.

Bouin, P.: 1924, cited after Sand, K., 1933.

Clermont, Y. \& Perey, B.: Amer. J. Anat., 1957, 100, 241.

Courot, M.: 1958, cited by Ortavant, R. in Reproduction in domestic animals, N.Y., $I I, 1$.

Del Castelo, E. B., Trabuco, A. \& De La Plaza, F. A.: J. clin. Endocrinol., 1947, 7, 493.

Hargit, G. T.: Amer. J. Morphol. 1926, 42, 253.

Hashimoto, Y. \& Eguchi, Y.: Jap. J. Zoot. Sci. 1955, 6, 259.

Hooker, C. W.: Amer. J. Anat., 1944, 74, 1.

Lageriöf, N.: Acta path. microbiol. scand., 1934, Suppl. 19, 5. Nord. Veterinärmötet, Copenhagen 1939.

Masui, K.: J. Coll. Agric., Tokyo, 1919, 3, 377.

Nicander, L., Abdel-Raouf, M. \& Crabo, B. (in press) : Acta Morphol. Neerlando-Scand.

Patterson, J. Th.: Anat. Anz., 1908, 32.

Regaud, Cl.: Bibliogr. Anat., 1900, 7, 24.

Romeis, B.: in Handbuch der Normalen und Pathologischen Physiologie, Berlin, 1926, 14, 693.

von Roth, O.: Zool. Anz., 1891, Jahr XIV.

Sand, K.: Die Physiologie des Hodens, in Hirsch (ed) Handbuch der inneren Sekretion, Leipzig, 1933, 2, 2017-2068.

Santamarina, E. \& Reece, R. P.: Amer. J. vet. Res., 1957, 18, 261.

Schinz, H. \& Slotopolsky, B.: Denkschr. schweiz. Naturforsch. 1924, 61, Abh. 2.

Stieve, H.: Handbuch der Mikroskopischen Anatomie des Menschen, Berlin, 1930, 7, 399.

\section{SUMMARY}

The epithelium of the sex cords and the seminiferous tubules is described from the foetal state to maturity. The basal supporting cells were observed to proliferate actively at and soon after birth, but their division ceased by the age of 16 weeks. Some of the new cells were observed to be located towards the centre of the sex cords by the age of four weeks. By the age of 28 weeks some of the supporting cells, which never give rise to spermatogonia, become transformed to typical Sertoli cells. By the age of 44 weeks all the supporting cells have been transformed into Sertoli cells.

Many gonocytes show degenerative changes shortly after birth. The gonocytes which do not degenerate, proliferate from the eighth 
week and give rise to spermatogonia. Spermatogonia increase in number and by the age of 20 weeks primary spermatocytes are produced. Spermatids and sperm appear by the age of 28 weeks.

\section{ZUSAMMENFASSUNG}

Die Proliferation von Samenzellen in den Hoden von Bullkälbern und Jungbullen.

Auf Grund einer Untersuchung der Hoden von 50 SRB-Bullen und eines Fötus wird das Epithel der Samenstränge bzw. Samenkanäle vom späten Fötusstadium bis zur vollen Entwicklung beschrieben. Proliferation wurde bei den basalen undifferenzierten Stützzellen vor und nach der Geburt sowie bis zum Alter von 16 Wochen nachgewiesen. Als ein Ergebnis dieser Proliferation wurden vom Alter von 4 Wochen undifferenzierte Stützzellen auch zentral in den Samensträngen wahrgenommen. Die undifferenzierten Stützzellen wandelten sich zu Sertolizellen um, bewirkten aber keine Spermatogonien. Typische Sertolizellen wurden vom Alter von 28 Wochen beobachtet. Im Alter von 44 Wochen hatten sich alle undifferenzierten Stützzellen zu Sertolizellen umgewandelt.

Kurze Zeit nach der Geburt wurden bei vielen Gonocyten degenerative Veränderungen festgestellt. Nichtdegenerierte Gonocyten zeigten Proliferation und bewirkten mit Beginn des Alters von 8 Wochen Spermatogonien. Die Anzahl von Spermatogonien nahm während der folgenden Wochen sukzessiv zu. Primäre Spermatocyten wurden vom Alter von 20 Wochen und Spermatiden sowie Spermien vom Alter von 28 Wochen wahrgenommen.

\section{SAMMANFATTNING \\ Utvecklingen av könsceller i testiklar hos tjurkalvar och ungtjurar.}

En beskrivning lämnas av sädessträngarnas resp. sädeskanalernas epitel från sent fosterstadium till full utveckling baserad på en undersökning av testiklar från 50 SRB-tjurar och ett foster. Proliferation iakttogs hos de basala odifferentierade stödjecellerna före och efter födelsen samt fram till 16 veckors ålder. Som ett resultat av denna proliferation iakttogs från 4 veckors ålder odifferentierade stödjeceller även centralt i sädessträngarna. De odifferentierade stödjecellerna omvandlades till Sertoliceller men gav icke upphov till spermatogonier. Typiska Sertoliceller observerades från och med 28 veckors ålder. Alla odifferentierade stödjeceller voro omvandlade till Sertoliceller vid 44 veckors ålder.

Kort tid efter födelsen observerades hos många gonocyter degenerativa förändringar. Gonocyter, som icke degenererade, visade proliferation och gav upphov till spermatogonier med början vid 8 veckors ålder. Antalet spermatogonier ökade under de följande veckorna successivt. Primära spermatocyter observerades från 20 veckors ålder samt spermatider och spermier från 28 veckors ålder. 